DOI https://doi.org/10.18551/rjoas.2021-02.18

\title{
WOMEN INVOLVEMENT IN AGRICULTURAL INNOVATION ADOPTION DECISION AMONG POTATO FARMING HOUSEHOLDS IN BOKKOS, PLATEAU STATE, NIGERIA
}

\author{
Mailumo S.S. \\ Department of Agricultural Extension and Management, Federal College of Forestry, Nigeria \\ E-mail: drmailumo247@gmail.com
}

\begin{abstract}
This study analyzed the involvement of women in agricultural innovation adoption decision among potato farming households in Bokkos Local government area Plateau State, Nigeria. Multistage sampling technique was used to select the respondents; data collected were analyzed using descriptive statistics, logit regression and Women in Agriculture Empowerment Index (WAEI). Results of the time use studies from this study revealed that women spend an average of 5 hours working on the family's farm. These women were receptive to adoption of agricultural innovation by the farming households. The result of the involvement of women in the decision to adopt agricultural innovation revealed that $57 \%$ of the women were empowered (involved) in the decision process. This indicates that women in the study area were integral in the processes that leads to the adoption of agricultural innovations. The determinants of adoption of agricultural innovations include age, educational level, household size and membership of cooperative society. Involvement of women in adoption decision and hours spend on farm per day were also significant. It is therefore recommended that this decision making empowerment should be leverage upon to enhance their livelihoods.
\end{abstract}

\section{KEY WORDS}

Women, involvement, innovation, adoption, decision.

The international development community has recognized that agriculture is an engine of growth and poverty reduction in countries where it is the main occupation of the poor (Anriquez, 2010). But the agricultural sector in many developing countries is underperforming, in part because women, who represent a crucial resource in agriculture and the rural economy through their roles as farmers, labourer and entrepreneurs, almost everywhere, face more severe constraints than men in access to productive resources. Efforts by national governments and the international community to achieve their goals for agricultural development, economic growth and food security will be strengthened and accelerated if they build on the contributions that women make and take steps to alleviate these constraints (Sofa and Cheryl, 2011).

Nigeria is the most populous country in Africa and has an estimated population of about 192 million people in 2017 which accounts for 47 per of West Africa's population (United Nation, 2017). Its domestic economy is dominated by agriculture, which accounts for about $40 \%$ of the Gross Domestic Product (GDP) and employ two-thirds of the labour force. Furthermore, agriculture supplies food, raw materials and generates household income for the majority of the people (Federal Office of Statistics, 2012). However, women have limited access to a wide range of physical assets including agricultural inputs, technological resources, land and so forth (Arndft and Tarp, 2000). Women are a key part of the mainstream in agriculture, yet they face formidable obstacles (Kandiwa, 2013).

Agriculture progresses technologically as farmers adopt innovations. The extent to which farmers adopt available innovation and the speed by which they do so determines the impact of innovations in terms of productivity growth. It is a common phenomenon that farmers like any other kind of entrepreneurs; do not adopt innovations simultaneously as they appear on the market. Apparently, some farmers choose to be innovators (first users) while others prefer to be early adopters, late adopters, or non- adopters (Paul et al., 2008). Increasing agricultural productivity is crucial to meet expected rising demand for food and as 
such, it is instructive to examine recent performance in cases of modern agricultural technologies (Challa, 2013). Agricultural technologies include all kinds of improved techniques and practices which affect the growth of agricultural output (Jain et al., 2009). According to Loevinsohn et. al., (2012) the most common area of technology development and promotions for crops include new varieties and management regimes; soil as well as soil fertility management; weed and pest management; irrigation and water management. By virtue of improved input / output relationship, new technology tend to raise output and reduces average cost of production which in turn results in substantial gains in farm income (Challa, 2013).

Adopters of improved technologies increase their productions, leading to constant socio-economic development. Adoption of improved agricultural technologies has been associated with higher earnings and lower poverty; improved nutritional status; lower staple food prices; increased employment opportunities as well as earnings for landless laborers (Kasirye and Katuagi, 2010). Adoption of improved technologies is believed to be a major factor in the success of the green revolution experienced by Asian countries (Ravallion and Chen, 2004; Kasirye and Katuagi, 2010) on the other hand, non-adopter can hardly maintain their marginal livelihood with socio-economic stagnation leading to deprivation (Jain et al., 2009).

Several empirical studies have found that female farmers have lower yields than male farmers (Larson et. al., 2015). It has been established by studies that women are likely to have less land to cultivate than men and when they do, tenure security may be weaken or totally unavailable (Doss, 2015; Cadzow, 2016). Secondly, their access to technology, information and agricultural extension tend to be more limited compared to men (Bravo Monroyet. al., 2016). In growing crops, women are more prone to be constrained in their access to inputs, resulting in lower levels of fertilizer, labour, and other inputs than is optional (Oseni et al., 2015, Cadzow, 2016). Management of the field may reveal constraints as well, ranging from lower or poor levels of education to trying to play dual roles as farm owners and household managers (Forsythe et. al., 2015).

In many parts of the world for example Sub-Saharan Africa (SSA) and South Asia despite women being the main farmers or producers, their roles are largely unrecognized. The poor, especially women, face obstacle in making their voices heard even in democratic systems and in increasing accountability and governance reforms in many areas (World Bank, 2007). For instance, recent studies stress that women's representation and gender integration into national plans and agricultural sector strategies remain a challenge (World Bank, 2005). This study is therefore an attempt to examine the involvement of women in agricultural innovation adoption decision among potato farming households in Bokkos Local Government Area, Plateau State Nigeria.

\section{METHODS OF RESEARCH}

The study was carried out in Bokkos Local Government Area of Plateau State, Nigera. It is one of the 17 Local Government Areas in the state. Though situated in the tropical zone, it has a high altitude of $1324 \mathrm{~m}$ and situated on latitude of $9.3^{\circ} \mathrm{N}$ and longitude of $90^{\circ} \mathrm{E}$. The area experience a near temperate climate with an average temperature of between $18^{\circ} \mathrm{C}$ and $22^{\circ} \mathrm{c}$. Harmattan winds cause the coldest weather between December and February. The warmest temperature usually occurs in the dry season months of March and April. The mean annual rainfall is $146 \mathrm{~cm}$ (57in). The highest rainfall is recorded during the wet season months of July and August. The local government area has a 2019 projected population of 255,067 people with a growth rate of $2.74 \%$. The LGA is largely rural and the people are mainly farmers. Potato is a major cash crop grown in the area.

Multistage sampling procedure was used to select 150 women farmers who were spouses. The first stage of the multistage sampling technique was the purposive selection of Bokkos Local Government Area out of the 17 Local Government Areas of Plateau State. Bokkos was selected because it produces potato more than any other local government area in Plateau State. In the second stage, simple random sampling was used to select 5 
districts namely (Batu, Daffo, Manguna, Munshere and Toff) because they are the major districts that produce potato. Third stage, 5 villages were purposively selected; namely Richa, Gada, Manguna, Munshere and Amban. While the sampling size was $10 \%$ of the sample frame.

Table 1 - Distribution of respondents from the five rural villages

\begin{tabular}{llll}
\hline S/n & Village & Sample frame & Sample size (10\% sample frame) \\
\hline 1 & Richa & 450 & 45 \\
2 & Gada & 250 & 25 \\
3 & Manguna & 400 & 40 \\
4 & Mushere & 300 & 30 \\
5 & Amban & 100 & 10 \\
& Total & 1500 & 150 \\
\hline
\end{tabular}

Primary data was generated for this study. The data was collected through the administration of questionnaire. The questionnaire was set based on the objective of the study. The data was analyzed using descriptive statistics, logit regression and women in agriculture empowerment index (WAEI).

Logit model was used to assess the factors that determine the involvement of women in agricultural innovation adoption decision among potato farming households in Bokkos. Logit regression analysis is a uni/multivariate technique which allows for estimating the probability that an event occurs or not, by predicting a binary dependent outcome from a set of independent variables. The linear probability model is depicted by Johnson and Wichern (1992) as:

$$
P_{i}=\in\left(\gamma=1 / X_{i}\right)=\beta_{1}+\beta_{2} X_{i}
$$

Where: $X i$ refers to the variables that influenced the decision to adopt agricultural innovation while $Y$ refers to whether the farmers adopt agricultural innovations. Let us consider the following representation of determinants of innovation adoption.

$$
P_{1}=\in\left(\gamma=1 / X_{i}\right)=\frac{1}{1+\exp \left[-\left(\beta_{1}+\beta_{2} X_{i}\right)\right]}=\frac{1}{1+\exp \left(-Z_{i}\right)}
$$

Where:

$$
Z_{i}=\beta_{1}+\beta_{2} X_{i}
$$

This equation (3) is known as the (cumulative) logistic distribution function. Here $Z_{i}$ ranges from $-\infty$ to $+\infty ; P_{i}$ ranges between 0 and $1 ; P_{i}$ is non-linearly related to $Z_{i}$ (i.e $X_{i}$ ) thus satisfying the two conditions required for a probability model. In satisfying these requirements, an estimation problem has been created because $P_{i}$ is non-linear not only in $X i$ but also in the $\beta^{\prime}$ s. This means that one cannot use OLS procedure to estimate the parameters. Here, $P_{i}$ is the probability of not adopting agricultural innovation is given by:

$$
\frac{1}{1+\exp \left(-Z_{i}\right)}
$$

Then $(1-P I)$, the probability of adopting agricultural innovation is:

$$
\left(1-P_{i}\right)=\frac{1}{1-\exp \left(z_{i}\right)}
$$

Therefore, one can write:

$$
\frac{P_{i}}{\left(1-P_{i}\right)}=\frac{1+\exp \left(Z_{i}\right)}{1+\exp \left(-Z_{i}\right)}
$$

$P_{i} /\left(1-P_{i}\right)$ is the odds ratio in favour of farmers adopting agricultural innovations i.e the ratio of the probability that a farming household will make a decision to adopt agricultural 
innovation on their farms to the probability that they will not. Taking natural log of $(Z)$, we obtain:

$$
L_{i}=\ln \left[P_{i} /\left(1-P_{i}\right)\right]=Z_{i}=\beta_{0}+\beta_{1} X_{1}+\cdots+\beta_{6} X_{6}+e
$$

That is, the log of the odds ratio is not only linear in Xs, but also linear in the parameters. $L$ is called the logit. The parameters to be estimated include the following:

- $\quad \mathrm{Zi}=1$ = adoption of agricultural innovation, 0 = otherwise;

- $\mathrm{X}_{1}-\mathrm{X}_{9}$ are vectors of explanatory variables which include:

$X_{1}=$ Age of farmers (years);

$\mathrm{X}_{2}=$ Gender;

$\mathrm{X}_{3}=$ Education (Years);

$\mathrm{X}_{4}=$ Farm size (Hectares);

$\mathrm{X}_{5}=$ Membership of cooperative society (Member $=1$, Non-member $=0$ );

$\mathrm{X}_{6}=$ Household size (Number);

$X_{7}=$ Involvement of women in adoption decision (Involve women = 1, Otherwise $=0$ );

$X_{8}=$ Income from sales of crops (A);

$\mathrm{X}_{9}=$ Hour spend on farm per day.

- $\mathrm{e}=$ error term.

The WEI sub- index shows how empowered women are, it captures the roles and extent of women's engagement in the agricultural sector in five domains: (1) decisions over agricultural production, (2) access to and decision-making power over productive resources, (3) control over used of income, (4) leadership in the community, and (5) time use. It assesses the degree to which women are empowered in these domains, and for those who are not empowered, the percentage of domains in which they are empowered.

$$
W E I_{\mathrm{all}}=\frac{\sum_{j=1}^{n} x_{j}}{d}
$$

Where: $\mathrm{WEI}_{\mathrm{all}}=$ women empowerment index for all decision per respondent; $x=$ value of decision maker; $j=$ code for the specific decision matter; $d=$ total number of decision replied by the respondent; $n=$ number of decisions.

The value of ranges from 1.00 to 5.00 :

- A value of 1.00 means that the male head tend to be sole decision maker;

- Any value below 3.00 but higher than 2.00 means the female head join in making the decision but the decision of male head dominates;

- A value of 3,00 means both the female and male head makes the decision jointly with equal contribution;

- A value near 5.00 and higher than 3.00 means that the female head dominates in decision making than the male head;

- A value of 5.00 means the female head is the sole decision maker.

\section{RESULTS AND DISCUSSION}

The result in Table 2 shows that the mean hours spent by women was 5 hours. The distribution showed that $69 \%$ spent $1-5$ hours while $31 \%$ spent $6-10$ hours. Several studies have shown that in Sub-Saharan Africa, both men and women engage in a number of productive and reproductive work activities. Time use studies from the region reveal that women spend more time than men at work, especially when their inputs in non-System of National Accounts (SNA) production, namely domestic and care work, are included. Moreover, children and adolescents - particularly girls - have important economic roles in their households. In Tanzania, girls at every age have heavier workloads than boys (Ritchie et al., 2004). In Uganda, girls work 21.6 hours per week, boys 18.8 hours. A cross-country study which includes two countries from the region, South Africa and Kenya, shows that girls spend more time than boys on non- SNA work in the form of domestic activities. 
Table 2 - Time (in Hours) spent on farm by women

\begin{tabular}{lll}
\hline Hours spent of farm & Frequency & Percentage \\
\hline $1-5$ & 52 & 69.33 \\
$6-10$ & 23 & 30.67 \\
$11-15$ & 0 & 0.00 \\
Total & 75 & 100 \\
Mean & 5 & \\
\hline
\end{tabular}

The agricultural innovation adopted and practiced by the farming households considered was plant spacing, growing high yielding varieties and watering (irrigation). The frequency distribution in Table 3 showed that $54 \%$ of the farming households adopted plant spacing innovation, 20\% were aware but had not yet adopted and $16 \%$ and $9 \%$ were not aware and not adopted respectively. This implies that the farming households adopted row spacing during planting. The farmers practiced close spacing which increases the number of plants per hectare thus increasing yield.

The result also shows that $57 \%$ of the farming households adopted high yielding varieties, $32 \%$ of them were aware, $7 \%$ were not aware and $5 \%$ of the respondents do not adopt. This implies that the respondents adopted high yielding varieties like Marabel which was the best yielding and Connect which was resistant to blight than the varieties they used before like Diamond, Nicola and Batista.

The result further reveal that $60 \%$ of the respondents were aware of irrigation, $33 \%$ adopted and $7 \%$ were not aware. This implies that majority of the farmers practice irrigation method and there is need for extension officers to enlighten them about the benefit of irrigation that could reduce the spread of the blight disease they were facing.

Table 3 - Adoption of innovation by women farmers

\begin{tabular}{llllll}
\hline Technology & Aware & Not aware & Adopted & Not adopted & Total \\
\hline Plant spacing & $30(20)$ & $25(16.7)$ & $81(54)$ & $14(9.3)$ & $150(100)$ \\
High yielding varieties & $48(32)$ & $10(6.6)$ & $85(56.67)$ & $7(4.66)$ & $150(100)$ \\
Irrigation & $90(60)$ & $10(6.66)$ & $50(33.33)$ & 0 & $150(100)$ \\
\hline
\end{tabular}

${ }^{*}$ Figures in parenthesis are percentages.

The result of the involvement of women in the decision to adopt agricultural innovation revealed that $57 \%$ women were empowered (involved) and $43 \%$ were disempowered (not involved). The adequacy level of empowerment was $80 \%$ and standard deviation of $2.32 \%$. This indicates that women in the study area were integral in the processes that leads to the adoption of agricultural innovations. In other words, their male spouses consult them before taking decisions to adopt innovations. This is only fair because studies have shown that in developing countries, most women's work is devoted to agriculture. Women are involved in every stage of food production. Although men usually plough the fields and drive draught animals, women do most of the work involved in sowing, weeding, fertilizing and harvesting the staple crops - such as rice, corn, potato and maize - which allows for more than 90 percent of the rural poor's diet.

Table 4 - Involvement of women in decision to adopt innovation

\begin{tabular}{lll}
\hline Involvement & Frequency & Percentage \\
\hline Involve & 85 & 57 \\
Not involve & 65 & 43 \\
Total & 150 & 100 \\
Standard deviation & 2.32 & \\
Adequacy level of empowerment & $80 \%$ & \\
\hline
\end{tabular}

The result of the regression in Table 5 showed that the age, educational level, Household size were negatively significant at $10 \%$ while farm size, membership of cooperative society were positively significant at $10 \%$. Involvement of women in adoption 
decision and hours spend on farm per day were positively significant at $1 \%$. The result revealed that the income from sales of crops of the respondents was negatively significant.

Age: the result of the regression of the socio-economic determinant of adoption, showed that an increase in the age of households will lead to a decrease in the adoption of agricultural innovation in the study area. Age has been found to have a negative relationship with adoption of technology. This relationship is explained by Mauceri et al. (2005) and Adesina and Zinnah (1993) that as farmers grow older, there is an increase in risk aversion and a decreased interest in long term investment in the farm. On the other hand younger farmers are typically less risk-averse and are more willing to try new technologies.

Educational level: The result reveal that educational level of the respondents was negatively significant at $10 \%$ for adopters. It shows that, the lesser the level of education of the respondents, the more likely they are to adopt agricultural innovation. This implies that a decrease in educational level of the respondents will lead to an increase in the adoption of innovation. Some authors have reported insignificant or negative effect of education on the rate of technology adoption (Grieshop et al., 1988; Khanna, 2001; Banerjee, et al., 2008; Samiee et al., 2009). Studying the effect of education on technology adoption, Uematsu and Mishra (2010) reported a negative influence of formal education towards adopting genetically modified crops. Since the above empirical evidence have shown mixed results on the influence of education and adoption of new technology, more study need to be done in order to come up with a more consistent result.

Members of cooperative society: The result of the analysis showed that membership of cooperative society was significant at $10 \%$. This implies that being members of cooperative society lead to increase in awareness of innovation of the respondents. Belonging to a social group enhances social capital allowing trust, idea and information exchange (Mignouna et al., 2011). Farmers within a social group learn from each other the benefits and usage of a new technology. Uaiene et al. (2009) suggests that social network effects are important for individual decisions, and that, in the particular context of agricultural innovations, farmers share information and learn from each other. Studying the effect of community based organization in adoption of corm-paired banana technology in Uganda, Katungi and Akankwasa (2010) found that farmers who participated more in community-based organizations were likely to engage in social learning about the technology hence raising their likelihood to adopt the technologies.

Table 5 - Determinants of involvement of women in decision to adopt innovation

\begin{tabular}{llll}
\hline Variable & Coefficient & Standard error & T-value \\
\hline Constant & -1.9276 & 1.0807 & $-1.78^{*}$ \\
Age & -0.0427 & 0.2412 & $-1.77^{*}$ \\
Gender & 0.1536 & 0.4812 & 0.3192 \\
Education & -0.0575 & 0.0319 & $1.80^{*}$ \\
Farm size & 0.0909 & 0.1754 & 0.52 \\
Membership of cooperative & 0.9749 & 0.5595 & $1.74^{*}$ \\
Household size & -0.0824 & 0.0499 & -1.65 \\
Involvement of women in adoption decision & 2.8469 & 0.5399 & -0.25 \\
Income from sales of crops & $-6.51 \mathrm{E}-07$ & $2.62 \mathrm{E}-06$ & $2.80^{* * *}$ \\
Hours spent on farm daily & 0.2787 & 0.0993 & \\
\hline Log likelihood function & -64.95 & & \\
Pseudo R2 & 0.27 & & \\
Prob>chi 2 & 0 & & \\
\hline
\end{tabular}

Note: ${ }^{* \star}$ significant at $1 \%$ and * significant at $10 \%$ levels of probability.

Women involvement in adoption: the result shows that, women involvement in adoption was positively significant at $1 \%$. This implies that, the more women were involved in the decision process to adopt decision agricultural innovation, the higher the probability of adopting the innovation. After all two good heads are better than one especially considering the number of hours women put into the farms. It has been reported that four often agricultural workers in the world are women (UN 1986). Women take part actively in farming activities and in processing farm products, in addition to their domestic and reproductive 
responsibilities. According to the Federal Ministry of Agriculture and Rural Development in 2008, women account for 75 percent of the farming population in Nigeria, working as farm managers, and suppliers of labour. Though women constitute a large portion of the farming population, women's possibilities in agriculture are hindered by formal and traditional rules. Generally, the extent of gender involvement in agricultural production varies across ethnic groups in Nigeria. (Sahel, 2014)

Hours spent on farm per day: the result of the regression revealed that, hours spent on farm per day was positively significant at $1 \%$. This implies that an increase in hours spent on farm will lead to increase on adoption innovation, because of time spent on farm. Time spend on the farm enables farmers to not just learn the existence as well as the effective use of technology but also facilitates its adoption. Farmers will only adopt the technology they are aware of or have heard about it. Access to information reduces the uncertainty about a technology's performance hence may change individual's assessment from purely subjective to objective over time (Bonabana- Wabbi 2002).

Table 6 - Challenges faced by women in adoption of innovation

\begin{tabular}{lll}
\hline Challenge & Frequency & Percentage \\
\hline Hiding of information by male spouse & 57 & 76.00 \\
High cost of fertilizer & 56 & 74.67 \\
Inadequate capital to purchase inputs & 53 & 70.67 \\
Too much activities on family farms & 51 & 68.00 \\
Lack of tractors to hire & 50 & 66.67 \\
Discrimination during selection to attend trainings & 48 & 64.00 \\
No enough extension agents & 45 & 60.00 \\
Shortage of labour when school is in session & 10 & 13.33 \\
\hline
\end{tabular}

The result revealed that $76 \%$ of the respondents were faced by the challenge of male counterpart hiding information, $75 \%$ reported that fertilizer was not available and where available, it was costly. Another $71 \%$ reported that they lacked capital to purchase other inputs especially seeds and labour, 68\% disliked the drudgery involved in farm activities which is time consuming. Unavailability of tractors to hire was reported by $67 \%$ of the respondents, 64\% reported that they were discriminated against attending local trainings. Inadequacy of extension agents was reported by $60 \%$ of the respondents and finally, $13 \%$ reported that their children don't assist them on the farms. Addressing these challenges will no doubt contribute to food security and enhancement of livelihoods among the farming households in the study area.

\section{CONCLUSION AND RECOMMENDATIONS}

Several studies have shown that in Sub-Saharan Africa, both men and women engage in a number of productive and reproductive work activities. Time use studies from this study revealed that women spend an average of 5 hours working on the family's farm. These women were receptive to adoption of agricultural innovation by the farming households. The result of the involvement of women in the decision to adopt agricultural innovation revealed that $57 \%$ of the women were empowered (involved) in the decision process. This indicates that women in the study area were integral in the processes that leads to the adoption of agricultural innovations. It is therefore recommended that this decision making empowerment should be leverage upon to enhance their livelihoods by assisting them to have more control over land resources.

\section{REFERENCES}

1. Adesina, A., and Zinnah, M. (1993). Technology characteristics, farmers' perceptions and adoption decisions: a Tobit model analysis in Sierra Leone. Agricultural Economics, 9

2. Anriquez, G. (2010). Demystifying the Agricultural Feminization Myth and the Gender Burden. Background paper prepared for The State of Food and Agriculture 2011. 
3. Arndt C. and Tarp F. (2000) Agricultural technology, risk and gender: A CGE anal ysis of Mozambique, World Development. Vol. 28, No.7, pp. 1307- 1326.

4. Banerjee, B., Martin, S., Roberts, R., Larkin, S., Larson, J., Paxton, K., English, B., Marra, M., and Reeves, J. (2008). A Binary logit estimation of factors affecting adoption of GPS guidance systems by cotton producers; Journal of agricultural and applied economics 40(1): 345-355

5. Bonabana-Wabbi J. (2002). Assessing Factors Affecting Adoption of Agricultural Technologies: The Case of Integrated Pest Management (IPM) in Kumi District, Msc. Thesis Eastern Uganda

6. Bravo-Monroy. L., Potts, S. G., and Tzanopoulos, J. (2016) Drivers influencing farmer decisionsfor adopting organic or conventional coffee management practices. Food Policy, 58, 49-61.

7. Cadzow, H. (2016). Empowering free town's women farmers Doctoral dissertation University of Otago. New Zealand.

8. Challa, M. (2013).Determining Factors and Impacts of Modern Agricultural Technology Adoption in West Wollega, Munich, GRIN Publishing GmbH, http://www.grin.com/en/ebook/280336/determiningfactors-and-impacts-of- modern-agricultural-technologyadoption.

9. Doss, C. R. (2015) Women and agricultural productivity: what does the evidence tell us? Yale University Economic growth centre discussion paper (1051).

10. Federal Office of Statistics. (2012) Gross Domestic Product for Nigeria. Available at www.nigerianstat.gov.ng.Accessed April 9th, 2017.

11. Fors ythe, L. Martin, A., \&Posthumus, H. (2015) Cassava market development: a path to women's empowerment or business as usual? Food Chain, -5(1-2),

12. Grieshop, I., Zalom, G., Miyao, G. (1988). Adoption and diffusion of integrated pest management innovations in agriculture: Bulletin of Entomological society of America: $72-$ 78

13. Jain R. Arora A \& Raju S. (2009). A Novel Adoption Index of Selected Agricultural Technologies: Linkages with Infrastructure and Productivity: Agricultural Economics Research Review 22; pp 109-120

14. Khanna, M. (2001). "Sequential Adoption of Site-Specific Technologies and Its Implications for Nitrogen Productivity: A Double Selectivity Model." American Journal of Agricultural Economics 83(1):35-51.

15. Kandiwa V. (2013) Mainstreaming gender in maize improvement research CIMMYT Report. http://dtma.cimmyt.org

16. Kasirye, A. and Katungi, E. (2010). Community-Based Organizations and their effect on the Adoption of Agricultural Technologies in Uganda: a studyof banana (Musa spp.) Pest Management Technology.

17. Katungi, E and Akankwasa, K. (2010). Community-Based Organizations and Their Effect on the Adoption of Agricultural Technologies in Uganda: a Study of Banana (Musa spp.) Pest Management Technology.

18. Loevinsohn M, Sumberg J, Diagne A (2012) under what circumstances and conditions does adoption of technology result in increased agricultural productivity? Protocol. London: EPPI Centre, Social Science Research Unit, Institute of Education, University of London

19. Mauceri, M., Alwang, J., Norton, G. Barrera, V. (2005). Adoption of Integrated Pest management Technologies: A Case Study of Potato Farmers in Carchi, Ecuador; Selected Paper prepared for presentation at the American Agricultural Economics Association Annual Meeting, Providence, Rhode Island, July 24-27, 2005.

20. Mignouna, B., Manyong, M., Rusike, J., Mutabazi, S., \& Senkondo, M. (2011). Determinants of Adopting Imazapyr-Resistant Maize Technology and its Impact on Household Income in Western Kenya: AgBioforum, 14(3), 158-163. Hall, B. and Khan, B. (2002) Adoption of new technology. New Economy Handbook.

21. Oseni, G, Paul C, Markus G, and Paul, W. (2015) Explaining gender differentials in agricultural production in Nigeria. Agricultural Economics, 46(3\285-310. 
22. Paul, D., Hans van, M., Arjan, W., and Katarzyna, B. (2003) Innovation Adoption In Agriculture: Innovators, Early Adopters And Laggards. Wageningen University and Research Centre, Agricultural Economics Research Institute. The Netherlands.

23. Ravallion, M., and Chen, S. (2004). "How have the world'spoorest fared since the early 1980s'.'"World Bank Research Observer, 19 (2): Ppl41-170.

24. Ricarde Hausman; Harcard university lauva D. Tyson, university of caliform Barkeleysaadikzahide world economic fost. The Global Gender Gop Report 2011.

25. Samiee, A., Rezvanfar, A., Faham, E. (2009). Factors affecting adoption of integrated pest management by wheat growers in Varamin County, Iran: African Journal of Agricultural Research 4(5); 491-497.

26. Sofa T. and Cheryl D. (2011).The role of women in agriculture. Agricultural Development Economics Division the Food and Agriculture Organization of the United Nationswww.iao.org/economic/esa. ESA Working Paper No. 11-02.

27. Sahel, A. (2014). The role of Nigeria Women in Agriculture system in Borno State, North-East Nigeria. Agriculture and Biology Journal of North America http://www.scihub.org/ABJNA.

28. UNDP (1986). World Survey on the Role of women in Development Published by Department of Social Sciences.

29. Uaiene, R., Arndt, C., Masters, W. (2009) Determinants of Agricultural Technology Adoption in Mozambique. Discussion papers No. 67E.

30. Uematsu, H., Mishra, A., (2010). Can Education Be a Barrier to Technology Adoption? Selected Paper prepared for presentation at the Agricultural \& Applied Economics Association 2010 AAEA, CAES, and WAEA Joint Annual Meeting, Colorado, 25-27.

31. World Bank (2005). Evaluating a Decade of World Bank Gender Policy: 1990-99. Operations Evaluation Department, World Bank, Washington, DC.

32. World Bank (2007). Global monitoring Report 2007: Millennium Development GoalsConfronting Challenges of Gender Equity and Fragile states. Washington, World Bank. 